Supporting Information

\title{
Highly Efficient Biofilm Eradication by Antibacterial Two-Dimensional Supramolecular Polymers
}

Anurag Mukherjee, ${ }^{\mathrm{a}_{\uparrow}}$ Ranajit Barman, ${ }^{\mathrm{a}} \uparrow$ Bidisa Das $^{\mathrm{b}}$ and Suhrit Ghosh ${ }^{\mathrm{a} *}$

a School of Applied and Interdisciplinary Sciences; ${ }^{\mathrm{b}}$ Technical Research Center; Indian Association for the Cultivation of Science, 2A and 2B Raja S. C. Mullick Road, Kolkata, India700032

$\uparrow$ Contributed equally

*Email-psusg2@iacs.res.in

Materials and methods. All the reagents and solvents were purchased from commercials sources and purified by standard protocols. ${ }^{1}$ 1,4,5,8-naphthalenetetracarboxylic dianhydride, dodecyl amine, octyl amine, cysteamine hydrochloride and 18-crown-6 were obtained from Sigma-Aldrich. Spectroscopy-grade solvents were used for all physical studies. ${ }^{1} \mathrm{H}$ NMR spectra were recorded in a Bruker DPX-400 MHz and Bruker DPX-300 MHz spectrometer and peaks were calibrated against TMS which was used as the internal standard. HRMS were recorded with an electron spray ionization (ESI) technique Q-tof-micro quadruple mass spectrometer (Micro mass). UV-Vis spectra were recorded in a JASCO V-750 UV-visible spectrometer with attached Peltier module and water circulator. Fluorescence emission spectral studies were carried out using Horiba FluoroMax-3 spectrophotometer. Perkin Elmer Spectrum 100FT-IR spectrometer was used for accumulating FT-IR spectra. PXRD of the dropcast films were recorded using a Rigaku SmartLab X-ray diffractometer $(\lambda=1.54 \AA)$ with a voltage of $40 \mathrm{kV}$ and current of $110 \mathrm{~mA}$ with Ni-filter equipped with 1D-detector. Multicell DSC from 
TA instrument was utilised for examining the thermodynamic parameters. Zeta potential measurements were carried out in a Malvern instrument. AFM images were captured in tapping mode in an Innova instrument from Bruker. TEM images were captured in a JEOL-2010EX instrument operating at an accelerating voltage of $200 \mathrm{KV}$. SEM images of bacteria were recorded with JEOL-JSM-7500F field-emission scanning electron microscopy (FE-SEM). Leica TCS SP8 instrument was utilized to check the biofilm viability. The absorbance of MTT and alamar Blue was measured by the microplate reader (VARIOSKAN, Thermo Fisher).

\section{Synthesis and characterizations.}
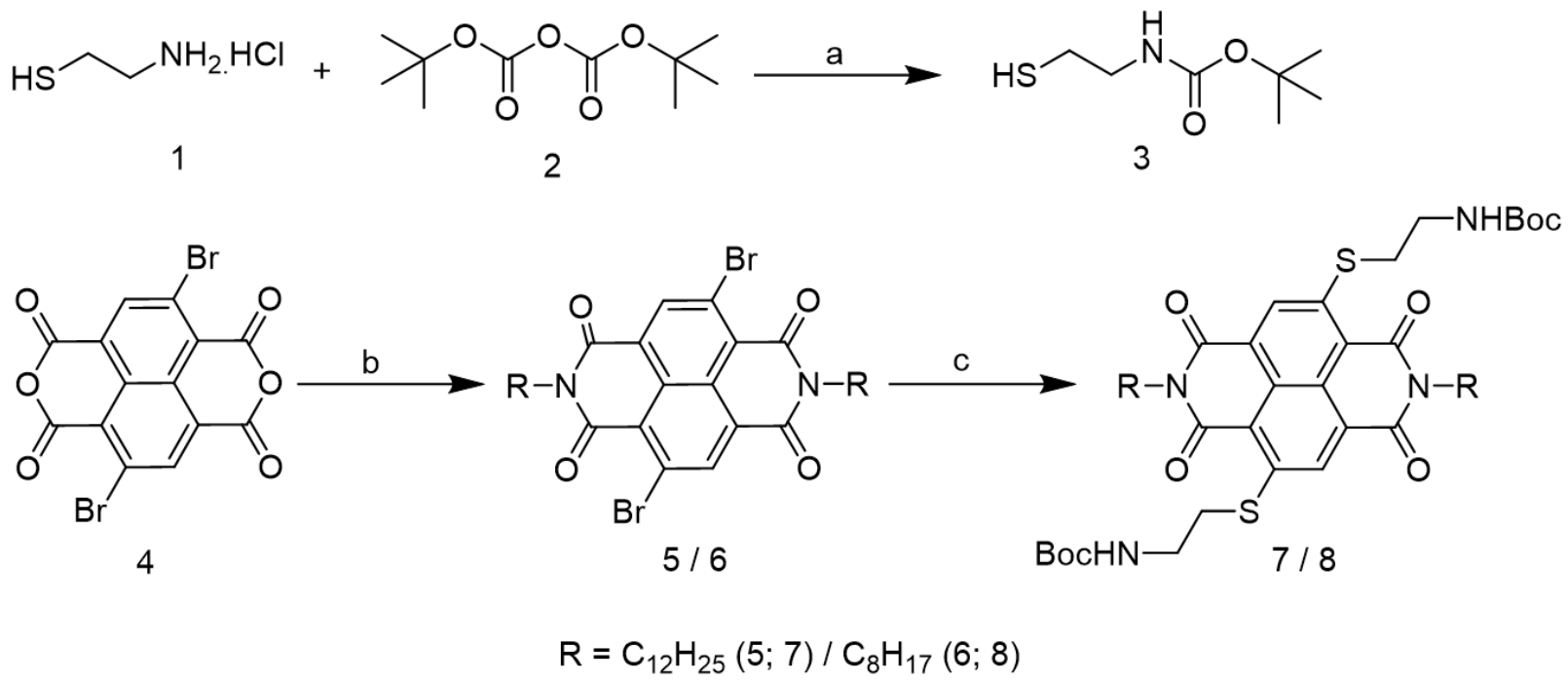

Reagents and conditions: (a) $\mathrm{Et}_{3} \mathrm{~N}, \mathrm{H}_{2} \mathrm{O}-\mathrm{THF}, 0^{\circ} \mathrm{C}$ to rt, $6 \mathrm{~h}, 90 \%$; (b) $\mathrm{C}_{12} \mathrm{H}_{25} \mathrm{NH}_{2} / \mathrm{C}_{8} \mathrm{H}_{17} \mathrm{NH}_{2}$, acetic acid, $100^{\circ} \mathrm{C}$, 8h, $50 \%$, (c) $3, \mathrm{~K}_{2} \mathrm{CO}_{3}, 18$-crown-6, toluene, $100^{\circ} \mathrm{C}, 8 \mathrm{~h}, 85 \%$.

Scheme S1. Synthetic scheme of compound 7 and 8.

Synthesis of compound 3. Compound $1(2.0 \mathrm{~g}, 17.6 \mathrm{mmol})$ was dissolved in $10 \mathrm{~mL}$ of distilled water along with triethylamine $(1.8 \mathrm{~g}, 2.5 \mathrm{~mL}, 17.8 \mathrm{mmol})$ and stirred in a round bottom flask to which a solution of compound $2(4.8 \mathrm{~g}, 5.0 \mathrm{~mL}, 22 \mathrm{mmol})$ in tetrahydrofuran $(10 \mathrm{ml})$ was added dropwise at ice cold condition. After the addition was complete, the reaction mixture was stirred for $6 \mathrm{~h}$ at room temperature. After removing THF using rotary evaporator, the reaction mixture was extracted with dichloromethane $(3 \times 50 \mathrm{~mL})$ and washed with brine solution $(2 \times 20 \mathrm{~mL})$. Combined organic layer was dried over anhydrous sodium sulphate and 
concentrated under vacuum to get the crude product as light-yellow oil which was used in the next step without further purification. Yield $=2.65 \mathrm{~g}(85 \%) .{ }^{1} \mathrm{H} \mathrm{NMR}\left(\mathrm{CDCl}_{3}, 400 \mathrm{MHz}\right.$, TMS): $\delta(\mathrm{ppm})=4.89(1 \mathrm{H}$, broad $) ; 3.33-3.26(2 \mathrm{H}, \mathrm{m}) ; 2.67-2.60(2 \mathrm{H}, \mathrm{m}) ; 1.44(9 \mathrm{H}, \mathrm{s}) ; 1.33$ (1H, m). HRMS (ESI): $\left[\mathrm{M}+\mathrm{H}^{+}\right]^{+}$calculated for $\mathrm{C}_{7} \mathrm{H}_{15} \mathrm{NO}_{2} \mathrm{~S}-178.0828$; found -178.0910 .

Synthesis of compound 4. Synthesis of compound 4 was carried out from naphthalenetetracarboxylic-dianhydride following a literature reported procedure. ${ }^{2}$

Synthesis of compound 5. Compound $4(400 \mathrm{mg}, 0.93 \mathrm{mmol})$ was taken together with dodecylamine $(690 \mathrm{mg}, 800 \mathrm{~mL}, 3.7 \mathrm{mmol})$ in acetic acid $(10 \mathrm{~mL})$ and the suspension was refluxed for $8 \mathrm{~h}$ under argon atmosphere while it became a clear solution. After that, the solution was allowed to cool to room temperature and poured into $100 \mathrm{~mL}$ ice-cold water leading to brownish yellow precipitation. The precipitate was filtered and the residue was washed with methanol ( $3 \times 15 \mathrm{~mL})$ to get off-white solid which was carried forward to the next step without further purifications. Yield: $367 \mathrm{mg}(52 \%) .{ }^{1} \mathrm{H} \mathrm{NMR}\left(\mathrm{CDCl}_{3}, 400 \mathrm{MHz}, \mathrm{TMS}\right): \delta$ $(\mathrm{ppm})=8.99(2 \mathrm{H}, \mathrm{s}) ; 4.21-4.15(4 \mathrm{H}, \mathrm{m}) ; 1.73-1.71(4 \mathrm{H}, \mathrm{m}) ; 1.37-1.25(36 \mathrm{H}, \mathrm{m}) ; 0.89-0.85$ (6H, m). HRMS (ESI): $\left[\mathrm{M}+\mathrm{H}^{+}\right]^{+}$calculated for $\mathrm{C}_{38} \mathrm{H}_{52} \mathrm{Br}_{2} \mathrm{~N}_{2} \mathrm{O}_{4}-759.2302$; found - 759.2591.

Synthesis of compound 6. Compound $4(400 \mathrm{mg}, 0.93 \mathrm{mmol})$ was taken together with octylamine (480 mg, $600 \mathrm{~mL}, 3.7 \mathrm{mmol})$ in acetic acid $(10 \mathrm{~mL})$ and the suspension was refluxed for $8 \mathrm{~h}$ under argon atmosphere while it became a clear solution. After that, the solution was allowed to cool to room temperature and poured into $100 \mathrm{~mL}$ ice-cold water leading to brownish yellow precipitation. The precipitate was filtered and the residue was washed with methanol ( $3 \times 15 \mathrm{~mL})$ to get an off-white solid which was carried forward to the next step without further purifications. Yield: $307 \mathrm{mg}(51 \%) .{ }^{1} \mathrm{H} \mathrm{NMR}\left(\mathrm{CDCl}_{3}, 400 \mathrm{MHz}\right.$, TMS): $\delta(\mathrm{ppm})=8.99(2 \mathrm{H}, \mathrm{s}) ; 4.21-4.15(4 \mathrm{H}, \mathrm{m}) ; 1.73-1.67(4 \mathrm{H}, \mathrm{m}) ; 1.37-1.26(20 \mathrm{H}, \mathrm{m}) ; 0.89-$ 
$0.85(6 \mathrm{H}, \mathrm{m}) . \mathrm{HRMS}(\mathrm{ESI}):\left[\mathrm{M}+\mathrm{H}^{+}\right]^{+}$calculated for $\mathrm{C}_{30} \mathrm{H}_{36} \mathrm{Br}_{2} \mathrm{~N}_{2} \mathrm{O}_{4}-646.1050$; found 647.1138 .

Synthesis of compound 7. Compound $5(300 \mathrm{mg}, 0.39 \mathrm{mmol})$ was dissolved in $8 \mathrm{~mL}$ dry toluene along with freshly dried potassium carbonate $(550 \mathrm{mg}, 4.0 \mathrm{mmol})$ and 18 -crown- 6 ether (20 $\mathrm{mg}, 0.078 \mathrm{mmol})$ and stirred for $15 \mathrm{~min}$ at $\mathrm{rt}$. To this solution, compound 3 (710 $\mathrm{mg}, 4.0$ mmol) was added and the reaction mixture was refluxed overnight under inert atmosphere. After that, toluene was removed in a rotary evaporator and the residual semi solid material was diluted by dichloromethane $(30 \mathrm{~mL})$ and washed with water $(3 \times 25 \mathrm{~mL})$. The organic part was further washed with brine $(2 \times 25 \mathrm{~mL})$ and dried over anhydrous sodium sulphate and concentrated under vacuum to get the crude product as deep red semi solid substance. Further purification was done by column chromatography with silica gel (100-200) as the stationary phase and MeOH:DCM $(0.75-1 \%)$ as the eluent to obtain the pure product as deep red solid. Yield: $315 \mathrm{mg}(85 \%) .{ }^{1} \mathrm{H} \mathrm{NMR}\left(\mathrm{CDCl}_{3}, 400 \mathrm{MHz}, \mathrm{TMS}\right): \delta(\mathrm{ppm})=8.62(2 \mathrm{H}, \mathrm{s}) ; 5.08(2 \mathrm{H}$, m); 4.20-4.15 (4H, m); 3.65-3.59 (4H, m); 3.42-3.38 (4H, m); 1.73-1.67 (4H, m); $1.45(18 \mathrm{H}$, bs); 1.37-1.18 (36H, m); 0.89-0.82 $(6 \mathrm{H}, \mathrm{m})$. HRMS (ESI): $\left[\mathrm{M}+\mathrm{Na}^{+}\right]^{+}$calculated for $\mathrm{C}_{52} \mathrm{H}_{80} \mathrm{~N}_{4} \mathrm{O}_{8} \mathrm{~S}_{2}-975.5316$; found - 975.5329.

Synthesis of compound 8. Compound $6(300 \mathrm{mg}, 0.46 \mathrm{mmol})$ was dissolved in $8 \mathrm{~mL}$ dry toluene along with freshly dried potassium carbonate $(635 \mathrm{mg}, 4.6 \mathrm{mmol})$ and 18 -crown- 6 ether (24 mg, $0.092 \mathrm{mmol}$ ) and stirred for $15 \mathrm{~min}$ at $\mathrm{rt}$. To this solution, compound 3 (814 $\mathrm{mg}, 4.6$ mmol) was added and the reaction mixture was refluxed overnight under inert atmosphere. After that, toluene was removed in a rotary evaporator and the residual semi solid material was diluted by dichloromethane $(30 \mathrm{~mL})$ and washed with water $(3 \times 25 \mathrm{~mL})$. The organic part was further washed with brine $(2 \times 25 \mathrm{~mL})$ and dried over anhydrous sodium sulphate and concentrated under vacuum to get the crude product as deep red semi solid substance. Further purification was done by column chromatography with silica gel (100-200) as the stationary 
phase and $\mathrm{MeOH}: \mathrm{DCM}(1-1.5 \%)$ as the eluent to obtain the pure product as deep red solid. Yield: $313 \mathrm{mg}(81 \%) .{ }^{1} \mathrm{H} \mathrm{NMR}\left(\mathrm{CDCl}_{3}, 400 \mathrm{MHz}, \mathrm{TMS}\right): \delta(\mathrm{ppm})=8.65(2 \mathrm{H}, \mathrm{s}) ; 5.05(2 \mathrm{H}$, m); 4.21-4.16 (4H, m); 3.63-3.59 (4H, m); 3.42-3.38 (4H, m); 1.73-1.65 (4H, m); $1.45(18 \mathrm{H}$, bs); 1.38-1.23 (20H, m); 0.89-0.80 (6H, m). HRMS (ESI): $\left[\mathrm{M}+\mathrm{Na}^{+}\right]^{+}$calculated for $\mathrm{C}_{44} \mathrm{H}_{64} \mathrm{~N}_{4} \mathrm{O}_{8} \mathrm{~S}_{2}-864.1258$; found - 864.1301.

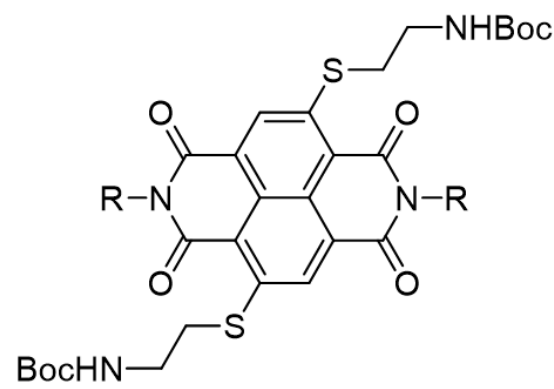

$7 / 8$

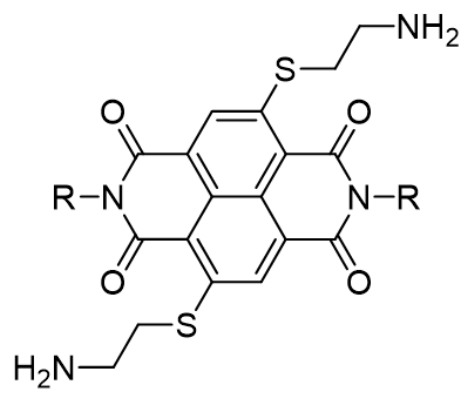

$\mathrm{R}=\mathrm{C}_{12} \mathrm{H}_{25}$ (7; cNDI-1; cNDI-2) / $\mathrm{C}_{8} \mathrm{H}_{17}$ (8; compound 9; cNDI-3)

Reagents and conditions: (d) TFA, DCM, $0^{\circ} \mathrm{C}$ to rt, 3h, $94 \%$; (b) $\mathrm{CH}_{3}$ l, methanol, $90^{\circ} \mathrm{C}$, 36h, sealed tube, $90 \%$.

Scheme S2. Synthetic scheme of cNDI based cationic amphiphiles.

Synthesis of cNDI-1. Compound $7(300 \mathrm{mg}, 0.315 \mathrm{mmol})$ was treated with $10 \%$ (v/v) trifluoroacetic acid in $5 \mathrm{~mL}$ anhydrous dichloromethane in inert atmosphere for $3 \mathrm{~h}$ while the progress of the reaction was monitored by TLC. After that, TFA was removed by vacuum evaporation and the residual semi solid reaction mixture was diluted by adding ethyl acetate $(25 \mathrm{~mL})$ and washed by sodium bicarbonate solution $(2 \times 25 \mathrm{~mL})$. After that, the organic part was further washed by distilled water $(2 \times 25 \mathrm{~mL})$ and followed by brine solution $(25 \mathrm{~mL})$ and dried over anhydrous sodium sulphate and concentrated under vacuum to get the product as 
dark red solid material which was used in the next step without any further purifications. Yield: $223 \mathrm{mg}(94 \%) .{ }^{1} \mathrm{H} \mathrm{NMR}\left(\mathrm{CDCl}_{3}, 400 \mathrm{MHz}, \mathrm{TMS}\right): \delta(\mathrm{ppm})=8.63(2 \mathrm{H}, \mathrm{s}) ; 4.18-4.13(4 \mathrm{H}, \mathrm{m})$; 3.38-3.30 (4H, m); 3.19-3.15 (4H, m); 1.70-1.68 (4H, m); 1.36-1.22 (36H, m); 0.86-0.82 (6H, m). HRMS (ESI): $\left[\mathrm{M}+2 \mathrm{H}^{+}\right]^{+}$calculated for $\mathrm{C}_{42} \mathrm{H}_{64} \mathrm{~N}_{4} \mathrm{O}_{4} \mathrm{~S}_{2}-754.4385$; found $-754.5375 .{ }^{13} \mathrm{C}$ NMR (75 MHz, $\left.\mathrm{CDCl}_{3}, \mathrm{TMS}\right): 163.33,162.26,148.01,145.05,128.18,125.30,123.78$, $121.65,119.50,45.59,41.35,40.53,36.38,32.05,29.78,29.71,29.49,28.17,27.33,22.83$, 14.26. Melting Point $-178 \pm 2{ }^{\circ} \mathrm{C}$. UV-Vis: Molar extinction coefficient ( $\varepsilon$ ) in THF $-8330 \mathrm{M}^{-1}$ $\mathrm{cm}^{-1}$ (at $368 \mathrm{~nm}$ ).

Synthesis of cNDI-2. In a small reaction tube, cNDI-1 (100 mg, $0.133 \mathrm{mmol})$ was taken along with methyl iodide (944 mg, $415 \mathrm{~mL}, 6.65 \mathrm{mmol}$ ) and $5 \mathrm{~mL}$ of methanol and the tube was sealed. Then the reaction mixture was stirred at $90{ }^{\circ} \mathrm{C}$ for $36 \mathrm{~h}$. The solvent and residual methyl iodide was removed by vacuum evaporation and the obtained dark brown pasty mass was purified by silica gel (100-200) column chromatography using $\mathrm{MeOH}$ : DCM (7-7.5\%) as the eluent to obtain the pure product as red solid. Yield: $136 \mathrm{mg}(90 \%) .{ }^{1} \mathrm{H}$ NMR (DMSO-d 6,400 MHz, TMS): $\delta(\mathrm{ppm})=8.58(2 \mathrm{H}, \mathrm{s}) ; 4.09-4.04(4 \mathrm{H}, \mathrm{m}) ; 3.83-3.80(4 \mathrm{H}, \mathrm{m}) ; 3.72-3.62(4 \mathrm{H}, \mathrm{m})$; $3.25(18 \mathrm{H}, \mathrm{s}) ; 1.71-1.60(4 \mathrm{H}, \mathrm{m}) ; 1.33-1.23(36 \mathrm{H}, \mathrm{m}) ; 0.86-0.82(6 \mathrm{H}, \mathrm{m})$. HRMS (ESI): [M + $\left.2 \mathrm{H}^{+}\right]^{+}$calculated for $\mathrm{C}_{48} \mathrm{H}_{78} \mathrm{~N}_{4} \mathrm{O}_{4} \mathrm{~S}_{2}-840.5470$; found - 840.5039. ${ }^{13} \mathrm{C} \mathrm{NMR}\left(75 \mathrm{MHz}, \mathrm{CDCl}_{3}\right.$, TMS):166.44, 165.02, 138.66, 132.18, 129.57, 129.41, 126.33, 124.32, 66.54, 53.96, 41.08, 31.72, 30.08, 29.64, 29.41, 29.39, 29.37, 28.81, 27.45, 27.12, 22.80, 14.13. Melting Point $173 \pm 2{ }^{\circ} \mathrm{C}$. UV-Vis: Molar extinction coefficient $(\varepsilon)$ in THF $-7570 \mathrm{M}^{-1} \mathrm{~cm}^{-1}$ (at $367 \mathrm{~nm}$ ).

Synthesis of compound 9. Compound $8(300 \mathrm{mg}, 0.356 \mathrm{mmol})$ was treated with $10 \%(\mathrm{v} / \mathrm{v})$ trifluoroacetic acid in $5 \mathrm{~mL}$ anhydrous dichloromethane in inert atmosphere for $3 \mathrm{~h}$ while the progress of the reaction was monitored by TLC. After that, TFA was removed by vacuum evaporation and the residual semi solid reaction mixture was diluted by adding ethyl acetate 
$(25 \mathrm{~mL})$ and washed by sodium bicarbonate solution $(2 \times 25 \mathrm{~mL})$. After that, the organic part was further washed by distilled water $(2 \times 25 \mathrm{~mL})$ and followed by brine solution $(25 \mathrm{~mL})$ and dried over anhydrous sodium sulphate and concentrated under vacuum to get the product as dark red solid material which was used in the next step without any further purifications. Yield: $214 \mathrm{mg}(92 \%) .{ }^{1} \mathrm{H}$ NMR (DMSO-d $\left.6,400 \mathrm{MHz}, \mathrm{TMS}\right): \delta(\mathrm{ppm})=8.50(2 \mathrm{H}, \mathrm{s}) ; 8.15(4 \mathrm{H}, \mathrm{bs})$; 4.08-4.02 (4H, m); 3.53-3.49 (4H, m); 3.25-3.22 (4H, m); 1.64-1.62 (4H, m); 1.32-1.25 (20H, m); 0.87-0.83 (6H, m). ${ }^{13} \mathrm{C}$ NMR (75 MHz, $\mathrm{CDCl}_{3}$, TMS): 164.07, 163.26, 147.77, 146.25, $129.01,125.93,123.90,121.32,119.81,45.59,41.07,40.33,34.48,33.39,29.73,29.68,29.48$, 28.33, 27.69, 22.79, 14.17. HRMS (ESI): $\left[\mathrm{M}+2 \mathrm{H}^{+}\right]^{+}$calculated for $\mathrm{C}_{34} \mathrm{H}_{48} \mathrm{~N}_{4} \mathrm{O}_{4} \mathrm{~S}_{2}-642.3133$; found -642.3329 . Melting Point $-171 \pm 2{ }^{\circ} \mathrm{C}$. UV-Vis: Molar extinction coefficient $(\varepsilon)$ in THF $-7620 \mathrm{M}^{-1} \mathrm{~cm}^{-1}$ (at $\left.367 \mathrm{~nm}\right)$.

Synthesis of cNDI-3. In a small reaction tube, compound 9 (100 $\mathrm{mg}, 0.156 \mathrm{mmol})$ was taken along with methyl iodide $(1.1 \mathrm{~g}, 485 \mathrm{~mL}, 7.81 \mathrm{mmol})$ and $5 \mathrm{~mL}$ of methanol and the tube was sealed. Then the reaction mixture was stirred at $90{ }^{\circ} \mathrm{C}$ for $36 \mathrm{~h}$. The solvent and residual methyl iodide was removed by vacuum evaporation and the obtained dark brown pasty mass was purified by silica gel (100-200) column chromatography using 8-9 \% $\mathrm{MeOH}$ in DCM as the eluent to obtain the pure product as red solid. Yield: $136 \mathrm{mg}(90 \%) .{ }^{1} \mathrm{H}$ NMR (DMSO-d 6,400 MHz, TMS $): \delta(\mathrm{ppm})=8.58(2 \mathrm{H}, \mathrm{s}) ; 4.09-4.04(4 \mathrm{H}, \mathrm{m}) ; 3.84-3.81(4 \mathrm{H}, \mathrm{m}) ; 3.73-3.70(4 \mathrm{H}, \mathrm{m})$; $3.26(18 \mathrm{H}, \mathrm{s}) ; 1.71-1.60(4 \mathrm{H}, \mathrm{m}) ; 1.33-1.23(20 \mathrm{H}, \mathrm{m}) ; 0.86-0.83(6 \mathrm{H}, \mathrm{m}) .{ }^{13} \mathrm{C}$ NMR $(75 \mathrm{MHz}$, $\left.\mathrm{CDCl}_{3}, \mathrm{TMS}\right): 162.89,161.63,144.59,127.25,124.80,124.14,119.70,62.57,52.41,31.22$ 28.96, 28.93, 28.85, 28.63, 27.30, 26.46, 23.70, 22.02, 13.89. HRMS (ESI): $\left[\mathrm{M}+2 \mathrm{H}^{+}\right]^{+}$ calculated for $\mathrm{C}_{40} \mathrm{H}_{62} \mathrm{I}_{2} \mathrm{~N}_{4} \mathrm{O}_{4} \mathrm{~S}_{2}-728.4218$; found - 727.4478. Melting Point - $165 \pm 2{ }^{\circ} \mathrm{C}$. UVVis: Molar extinction coefficient (ع) in THF $-8090 \mathrm{M}^{-1} \mathrm{~cm}^{-1}$ (at $367 \mathrm{~nm}$ ). 


\section{Experimental details.}

Bacterial preparation. All bacteria were grown aerobically at $37^{\circ} \mathrm{C}$ in Luria Bertani broth/ agar and was harvested at logarithmic growth phase $\left(\mathrm{OD}_{600}=0.6\right.$ to 1$)$ and used for further experiments. S. aureus (ATCC 25923) and E. coli (ATCC 25922) were purchased from ATCC, USA.

Minimum inhibitory concentration (MIC) determination. MIC of all the cNDI solutions were determined by the broth microdilution assay. A stock solution of $1.0 \mathrm{mg} / \mathrm{mL}$ concentration of each cNDI was prepared in aqueous medium following the procedure described in the experimental section of the manuscript. Samples were serially diluted in LB broth in noncoated polypropylene 96-well plate for getting different concentrations of the sample. Then $50 \mu \mathrm{L}$ of bacterial solution were added to each well where final inoculum concentration of cells in each well is approximately $5 \times 10^{5} \mathrm{CFU} / \mathrm{mL}$. Broth alone and broth containing only cells were considered as sterility control and growth control, respectively. The 96 well plate was incubated at $37^{\circ} \mathrm{C}$ for $18 \mathrm{~h}$ with gentle shaking at $180 \mathrm{rpm}$. The MIC was taken as the lowest concentration of a given cNDI at which there was $100 \%$ reduction of growth which was evident from cursory observation. All experiments were performed in triplicate.

Zone inhibition assay. Zone inhibition assay was done on LB agar plate. $100 \mu \mathrm{L}$ of bacterial solution in LB broth $\left(c=10^{8} \mathrm{CFU} / \mathrm{mL}, \mathrm{OD}_{600}=0.1\right)$ was spread on agar plate by a glass spreader to prepare lawns of bacteria. Then paper discs soaked with $20 \mu \mathrm{L}$ of cNDI solution $(c$ $=1.0 \mathrm{mg} / \mathrm{mL}$ ) was placed to the agar plates and incubated at $37^{\circ} \mathrm{C}$ for $18 \mathrm{~h}$. After the incubation no growth circle was observed around the paper disc which indicates the bactericidal activity of all three cNDI samples. 
Hemolysis assay. $1.0 \mathrm{~mL}$ of freshly drawn human blood from a healthy donor was suspended in $9 \mathrm{~mL}$ of cold PBS buffer ( $\mathrm{pH}$ 7.4) and centrifuged at $2000 \mathrm{rpm}$ for $5 \mathrm{~min}$. After pipetting out the supernatant, the precipitated RBCs were resuspended in cold PBS. This washing was repeated for two additional times. Then the collected RBC pellets were suspended in $10 \mathrm{~mL}$ of same PBS buffer and again diluted four times to get a $2.5 \%(\mathrm{v} / \mathrm{v})$ of RBC solution. Then $50 \mu \mathrm{L}$ of different concentrated cNDIs solutions were prepared by serial dilution method in a sterile 96-well round-bottom polypropylene plate, and $150 \mu \mathrm{L}$ of $\mathrm{RBC}$ suspension $(2.5 \%$, v/v) was added to each well and incubated for $2 \mathrm{~h}$ at $37{ }^{\circ} \mathrm{C}$ with shaking at $180 \mathrm{rpm}$. Triton $\mathrm{X}-100$ in water $(0.1 \% \mathrm{v} / \mathrm{v})$ and PBS were considered as positive and negative lysis control, respectively. After that $100 \mu \mathrm{L}$ of supernatant from each well was transferred to a sterile 96 -well flat-bottom polystyrene plate and was diluted with $100 \mu \mathrm{L}$ of PBS buffer. The absorbance of the released haemoglobin from lysed RBCs at $414 \mathrm{~nm}$ was determined using a Varioskan microplate reader (Thermo Fisher). The percentage of hemolysis by these cNDI sheets was calculated comparing the positive and negative control solvents.

Cytotoxicity assay using MTT. Hela cells with a seeding density of approximately $6 \times 10^{4}$ cells / well were seeded in 96-well plate for $24 \mathrm{~h}$. Then the medium was withdrawn and $100 \mu \mathrm{L}$ of the cNDI solutions of different concentrations ranging from $200 \mu \mathrm{g} / \mathrm{mL}$ to $25 \mu \mathrm{g} / \mathrm{mL}$ were added in different wells. The cells were then incubated for $12 \mathrm{~h}$. After each time point, $50 \mu \mathrm{L}$ of freshly prepared $5 \mathrm{mg} / \mathrm{mL}$ concentrated 3-(4,5-dimethylthiazol-2-yl)-2,5diphenyltetrazolium bromide (MTT) solution in media was added into each well and incubated for $4 \mathrm{~h}$ at $37^{\circ} \mathrm{C}$. Then, the MTT solution was carefully removed from each plate and $200 \mu \mathrm{L}$ of DMSO was added and the plate was gently shaken for 5-10 min at room temperature to dissolve all precipitate. The absorbance of MTT at $570 \mathrm{~nm}$ was recorded by a microplate reader (VARIOSKAN, Thermo Fisher). Cell viability was expressed by the ratio of absolute 
absorbance of the cells incubated with the cNDI solution to that of the cells incubated with only the culture medium.

Live/dead assay using fluorescence microscopy. $10^{9} \mathrm{CFU} / \mathrm{mL}$ concentrated solution of latelog phase $\left(\mathrm{OD}_{600} \sim 1\right)$ E. coli (ATCC 25922) or S. aureus (ATCC 25923) was prepared in 0.85 $\% \mathrm{NaCl}$ solution. Then, $100 \mu \mathrm{L}$ of this bacterial suspension was mixed with $100 \mu \mathrm{L}$ of cNDI solution (final concentration, $c=10 \times \mathrm{MIC}$ ) and incubated for $2 \mathrm{~h}$ at $37^{\circ} \mathrm{C}$. An aliquot of only E. coli/ S. aureus in the absence of any cNDI was used as a live-cell control. After that, $1.5 \mu \mathrm{L}$ of LIVE/ DEAD ${ }^{\mathrm{TM}}$ BacLight ${ }^{\mathrm{TM}}$ Bacterial Viability Kit (1:1 (v/v) mixture of Syto 9 (3.34 mM in DMSO) and propidium iodide (20 mM in DMSO) was added to the bacterial suspension in $0.85 \% \mathrm{NaCl}$ solution and incubated for $15 \mathrm{~min}$ in the dark. Then the extra dye was removed by precipitation followed by resuspension of the bacteria with $0.85 \% \mathrm{NaCl}$ solution. Next, 10 $\mu \mathrm{L}$ of this stained bacterial suspension was drop-casted on a clean microscope slide and covered with a glass lid, and imaging was done using an inverted fluorescence microscope (Olympus IX73, Tokyo, Japan).

Outer membrane permeabilization assay. The outer membrane permeabilization of $E$. coli bacteria by cNDI-1 and cNDI-2 sheets was monitored using NPN (N-phenylnapthylamine) as a hydrophobic fluorescence probe. $E$. coli cells $\left(\mathrm{OD}_{600}=1.0\right)$ were cultured in the LB media. Then cells were harvested by centrifugation, washed, and resuspended in $5 \mathrm{mM}$ HEPES buffer solution with $5 \mathrm{mM}$ glucose at $\mathrm{pH} 7.2$. Then, to $1.0 \mathrm{~mL}$ cell suspensions $\left(2 \times 10^{8} \mathrm{CFU} / \mathrm{mL}\right)$, $10 \mu \mathrm{L}$ of NPN solution ( $3 \mathrm{mM}$, in acetone) was added which gives a working concentration of NPN as $30 \mu \mathrm{M}$. From here $200 \mu \mathrm{L}$ solution was taken to a cuvette and mixed homogeneously with $10 \mu \mathrm{L}$ of $2 \mathrm{mg} / \mathrm{mL}$ concentrated solution of cNDI-1/ cNDI-2 (final concentration, $c=100$ $\mu \mathrm{g} / \mathrm{mL}$ ) and spectra was recorded in one-minute time intervals for $10 \mathrm{~min}$ at excitation and emission wavelengths of $350 \mathrm{~nm}$ and $420 \mathrm{~nm}$, respectively (slit width $=5.0 \mathrm{~nm}$ ). The 
fluorescence intensity of NPN increased with time as the hydrophobic NPN dye localised in the lipid membrane due to the disruption of the outer membrane by the cationic cNDI sheets.

Inner-membrane permeabilization assay. Inner membrane permeability was tested using propidium iodide (PI) as a fluorescence reference. First, bacteria were cultured in the LB media for $6 \mathrm{~h}\left(\mathrm{OD}_{600} \sim 1.0\right)$ and cells were harvested by centrifugation at $4000 \mathrm{rpm}$ for $10 \mathrm{~min}$. Then the cells were washed and resuspended in PBS buffer at $\mathrm{pH}$ 7.2. Then to a $0.2 \mathrm{~mL}$ cells suspension $\left(c=10^{8} \mathrm{CFU} / \mathrm{mL}\right), 10 \mu \mathrm{L}$ of $2 \mathrm{mg} / \mathrm{mL}$ concentrated solution of cNDI-1/ cNDI-2 was added and incubated for $2-3$ min at $37{ }^{\circ} \mathrm{C}$ with gentle shaking at $180 \mathrm{rpm}$. Next $6 \mu \mathrm{L}$ of PI stock solution of $0.5 \mathrm{mM}$ concentration was added to the cell suspension (final concentration of PI $=15 \mu \mathrm{M})$ and fluorescence spectra were recorded in an interval of one minute for a span of 10 min with excitation and emission wavelength of $535 \mathrm{~nm}$ and $617 \mathrm{~nm}$, respectively (slit width for both: $5 \mathrm{~nm}$ ). The fluorescence intensity started to increase as PI uptake happened due to the inner membrane permeabilization upon interaction with cNDI sheets.

Membrane depolarization assay. Depolarization of cytoplasmic membrane of $E$. coli/ $S$. aureus by cNDI-1 or cNDI-2 was monitored using potential sensitive dye, 3,3'dipropylthiacarbocyanine $\left(\operatorname{diSC}_{3}(5)\right)$. Firstly bacteria were grown to a logarithmic phase $\left(\mathrm{OD}_{600}=1.0\right)$ in LB media and centrifuged, washed, and resuspended in a buffer composing 5 $\mathrm{mM}$ HEPES, $20 \mathrm{mM}$ glucose, and $100 \mathrm{mM} \mathrm{KCl}$ at $\mathrm{pH}$ 7.2. Then to a $1.0 \mathrm{~mL}$ of bacteria solution in this buffer containing approximately $2 \times 10^{7}$ cells, $5 \mu \mathrm{L}$ of $10 \mu \mathrm{M} \operatorname{diSC}_{3}(5)$ solution was added and mixed well (final concentration of dye $=50 \mathrm{nM}$ ). The fluorescence spectra of the dye were recorded in each $30 \mathrm{sec}$ time intervals for $10 \mathrm{~min}$ at $25^{\circ} \mathrm{C}$ at an excitation wavelength of $622 \mathrm{~nm}$ and an emission wavelength of $670 \mathrm{~nm}$. Fluorescence intensity of the dye decreased with time as the dye localised in the membrane, resulting self-quenching. After $5 \mathrm{~min}$, maximum dye uptake in the membrane was observed and then $10 \mu \mathrm{L}$ of $2 \mathrm{mg} / \mathrm{mL}$ solution of cNDI-1/ cNDI-1 (final concentration $=100 \mu \mathrm{g} / \mathrm{mL}$ ) was added to the cell suspension. The 
fluorescence intensity increased gradually as the membrane potential decreases due to the interaction of membrane with cNDI-sheets and followed by release of the dye. Measurements were repeated at least twice under each condition.

Scanning electron microscopy (SEM). To a $500 \mu \mathrm{L}$ of bacterial [E. coli (ATCC 25922) and S. aureus (ATCC 25923)] suspensions in LB broth $\left(c=10^{9} \mathrm{CFU} / \mathrm{mL}\right), 500 \mu \mathrm{L}$ of cNDI-1/ cNDI-2 solution ( $c=400 \mu \mathrm{g} / \mathrm{mL}$ ) was added and the solution was incubated for $4 \mathrm{~h}$ at $37{ }^{\circ} \mathrm{C}$, and then the suspensions were harvested at $4000 \mathrm{rpm}$ for $10 \mathrm{~min}$. Then pellets were washed with $0.85 \% \mathrm{NaCl}$ solution twice. Next, cells were resuspended in $2.5 \%$ glutaraldehyde in PBS and incubated at room temperature for $30 \mathrm{~min}$ and kept it for overnight at $4{ }^{\circ} \mathrm{C}$. Then, the solution was centrifuged to collect the cells and washed with DI water twice. Dehydration of the sample was done in different ethanol grades $(10,30,50,70,80,90$, and $100 \%)$ keeping the solution at room temperature for $15 \mathrm{~min}$ in each step. After that, $10 \mu \mathrm{L}$ of cell solution in $100 \%$ alcohol was drop-casted on glass plate and Pt scattering was done for $1.5 \mathrm{~min}$ and images were captured using a JEOL-JSM-7500F field-emission scanning electron microscope at 5.0 $\mathrm{kV}$ voltage for both the bacteria.

Biofilm susceptibility. Biofilm susceptibility can be assessed using a very simple method employing the alamar Blue dye as a marker which can be reduced by metabolically active cells from indigo blue to fluorescent pink. In brief, $100 \mu \mathrm{L}$ of medium containing $10^{7} \mathrm{CFU} / \mathrm{mL}$ cells was added in different wells of a flat-bottomed 96-well plate and incubated at $37^{\circ} \mathrm{C}$ for $4 \mathrm{~h}$ in static condition to adhere the cells on the bottom surface in each well. Then the supernatant with non-adherent cells was removed carefully and washed twice with $100 \mu \mathrm{L}$ of $0.85 \% \mathrm{NaCl}$ (w/v) solution. Then $100 \mu \mathrm{L}$ fresh medium was added to well and further incubated for $24 \mathrm{~h}$ and after that the supernatant media was removed and rinsed with $100 \mu \mathrm{L}$ of $0.85 \% \mathrm{NaCl}$ solution. Next, solutions of different concentrations of cNDI-1 and cNDI-2 were prepared by serial dilution with LB media and $100 \mu \mathrm{L}$ of every solution was added to each well and control 
was made by adding $100 \mu \mathrm{L}$ of only medium without any cationic sheets. The plate was incubated for $3 \mathrm{~h}$ at $37^{\circ} \mathrm{C}$ in static condition and after that the supernatant was removed and washed with $0.85 \% \mathrm{NaCl}$ solution. Then $100 \mu \mathrm{L}$ of alamar Blue solution from a stock solution prepared by ten times dilution in $0.85 \% \mathrm{NaCl}$ of commercially available alamar Blue solution (purchased from Thermo Fisher) was added to each well and incubated in dark for 5-7 h. The fluorescence intensity was recorded at an excitation wavelength of $570 \mathrm{~nm}\left(\lambda_{\mathrm{ex}}=570 \mathrm{~nm}\right)$ and an emission wavelength of $590 \mathrm{~nm}\left(\lambda_{\mathrm{em}}=590 \mathrm{~nm}\right)$ and excitation band width of $5 \mathrm{~nm}$ using a microplate reader. The percentage of biofilm killing (\% of B.K) was estimated by following formula,

$\%$ of $\mathrm{B} . \mathrm{K}=[($ Fluorescence intensity of control - Fluorescence intensity of tested well $) /$ Fluorescence intensity of control] $\times 100$.

CFU reduction assay. $24 \mathrm{~h}$ aged biofilm of $S$. aureus or E. coli was formed in a 96 well plate following the similar procedure described before in context of the alamar Blue assay. Then biofilm was washed with $0.85 \% \mathrm{NaCl}$ solution three times. Next $100 \mu \mathrm{L}$ of different concentration of $2 \mathrm{D}$ sheet containing media was added in each well and the plate was incubated at $37^{\circ} \mathrm{C}$ for $6 \mathrm{~h}$. After that, the media from each well was removed, biofilms were washed three times with $100 \mu \mathrm{L} \mathrm{NaCl}$ solution to remove planktonic cells and biofilms were regrown overnight at $37^{\circ} \mathrm{C}$ in $100 \mu \mathrm{L}$ fresh media. Then the supernatant from each well was transferred to a fresh 96-well plate and the OD at $600 \mathrm{~nm}$ was measured using a plate reader. \% of CFU reduction was calculated comparing the positive and negative control.

Biofilm eradication assay (Crystal violet assay). $24 \mathrm{~h}$ aged biofilm of E. coli or $S$. aureus was treated with solutions of a given cNDI molecule of varying concentration in LB media similar to alamar Blue assay for $6 \mathrm{~h}$. Then wells were thoroughly washed with $0.85 \% \mathrm{NaCl}$ solution. Next, $0.4 \%$ crystal violet $(200 \mu \mathrm{L})$ was added to each well and incubated for $45 \mathrm{~min}$. 
Then the wells were washed with double distilled water for three times to remove any unbound dye. After adding $200 \mu \mathrm{L}$ of $30 \%$ acetic acid to each well, the plate was shaken for 15 min to release the dye. Biofilm formation was quantified by measuring the difference between absorbance of untreated and treated bacterial samples for each tested concentration of the cationic sheet and the absorbance of appropriate blank well at $600 \mathrm{~nm}$ using microplate reader plate reader.

Confocal microscopy of biofilm. This biofilm viability was visualized by confocal microscopy using the Live/Dead Bac Light $^{\mathrm{TM}}$ kit (Invitrogen). First bacterial solution in LB media was added in confocal disc and incubated for $3 \mathrm{~h}$ in static condition at $37^{\circ} \mathrm{C}$ to adhere on the surface and next supernatant was carefully removed and $100 \mu \mathrm{L}$ fresh LB media was added and incubated for another $24 \mathrm{~h}$. Then supernatant was again removed and $100 \mu \mathrm{L}$ of cNDI-1 and cNDI-2 solutions having $150 \mu \mathrm{g} / \mathrm{mL}$ concentration was added and incubated for $3 \mathrm{~h}$ and then supernatant was removed. Then $100 \mu \mathrm{L}$ of staining solution $(1.5 \mu \mathrm{L}$ of Syto- 9 and $1.5 \mu \mathrm{L}$ propidium iodide was mixed in $100 \mu \mathrm{L} 0.85 \% \mathrm{NaCl}$ solution) was added and incubated for $15 \mathrm{~min}$ in the dark. Then the solution was taken out and washed with $0.85 \% \mathrm{NaCl}$ solution to remove extra dye. The biofilm viability was checked by confocal laser scanning microscopy (CLSM) in Leica TCS SP8 instrument.

\section{Additional figures}



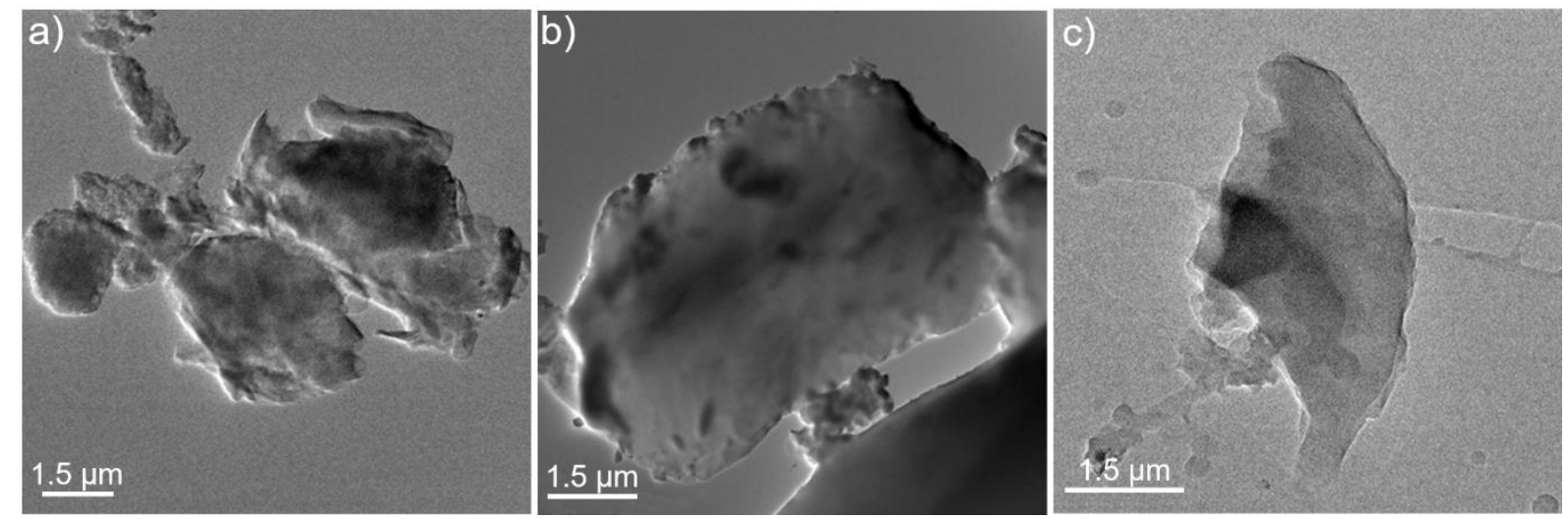

Figure S3. TEM images of (a) cNDI-1, (b) cNDI-2 and (c) cNDI-3. TEM samples were prepared from their aqueous solution $(c=0.1 \mathrm{mM}, \mathrm{pH}=6.2)$. 

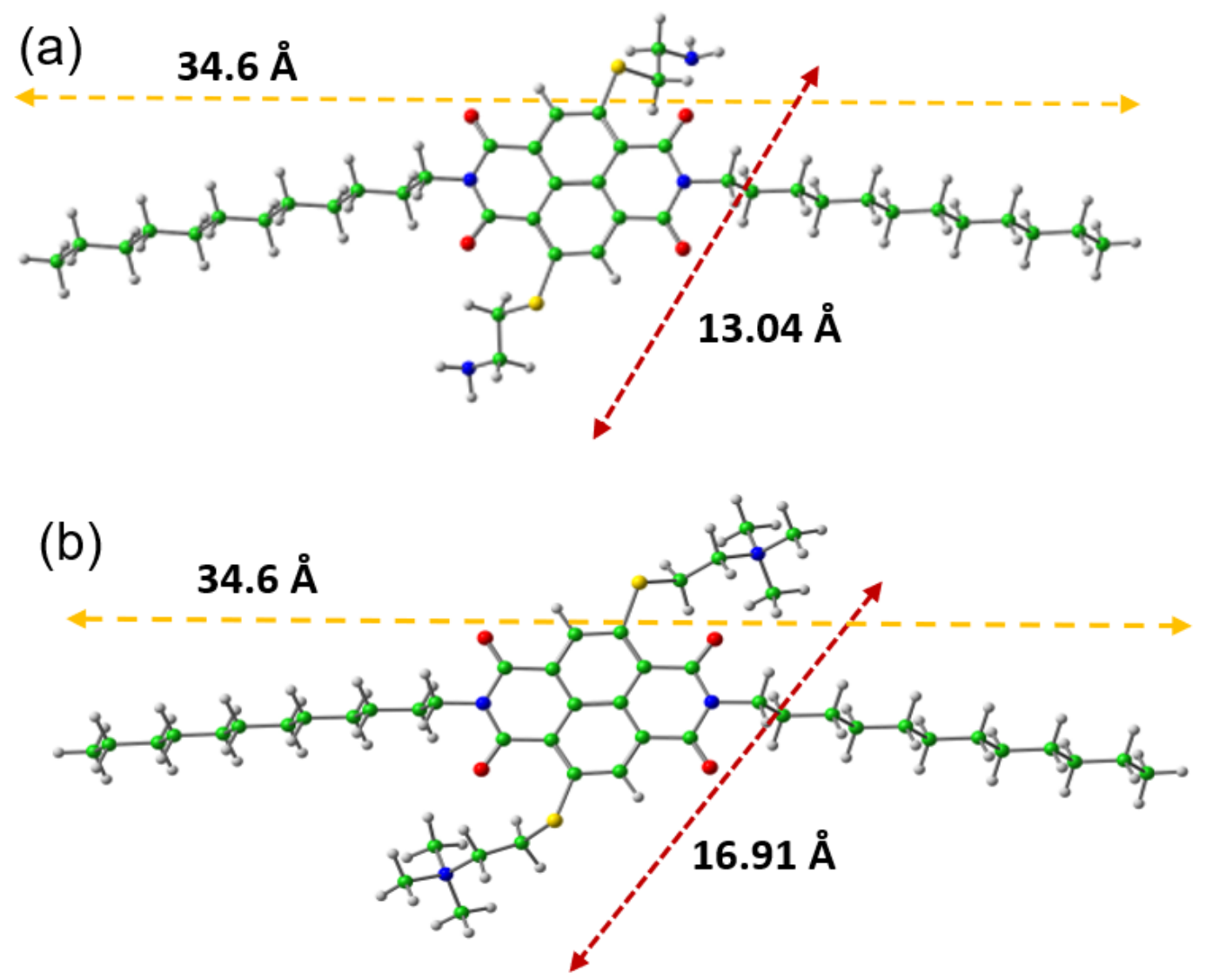

(c)

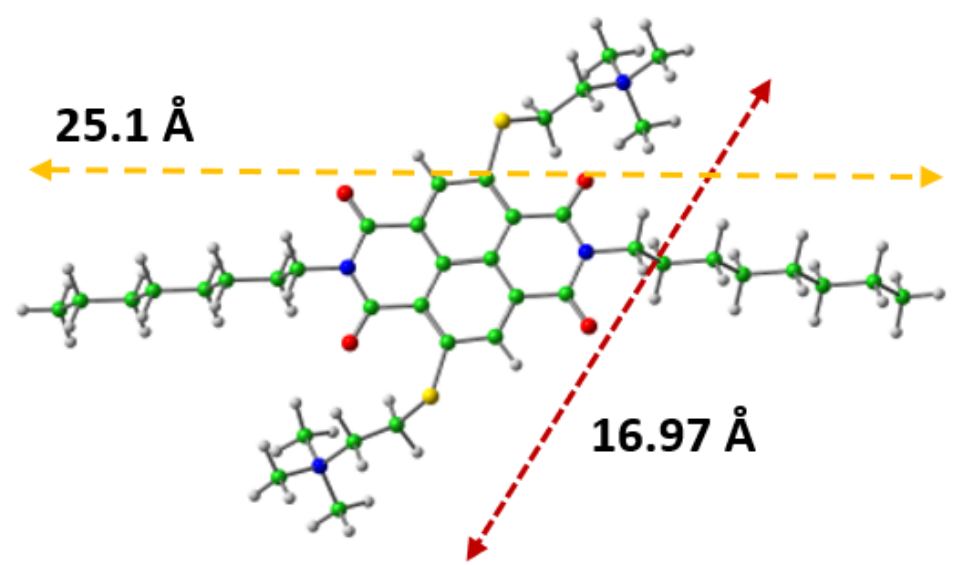

Figure S4. Optimized molecular structures of (a) cNDI-1, (b) cNDI-2 and (c) cNDI-3 calculated using DFT. The lengths and widths of the molecules are shown by arrows. In the structures C: green balls, N: Blue balls, O: red balls, S: yellow balls and small white balls are all $\mathrm{H}$ atoms. 


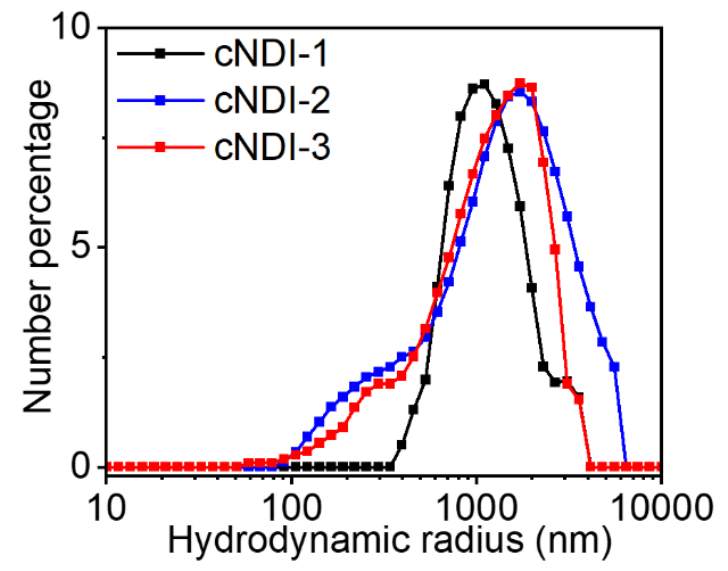

Figure S5. Size distribution of the aqueous aggregates of cNDI-1, cNDI-2 and cNDI-3 in water $(c=0.1 \mathrm{mM}, \mathrm{pH}=6.2)$ from DLS.

a)

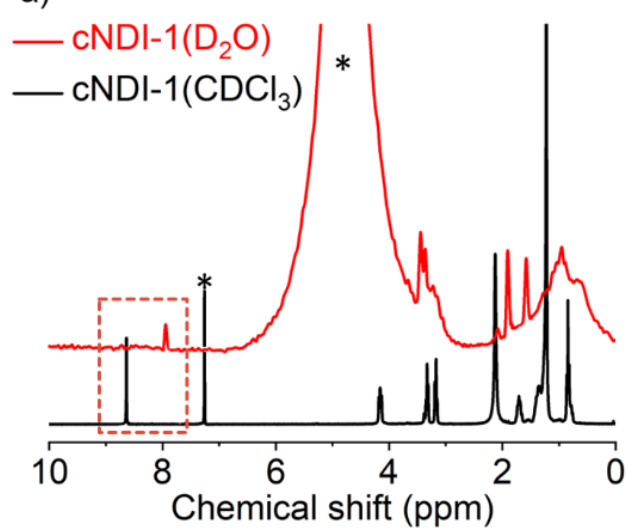

b)

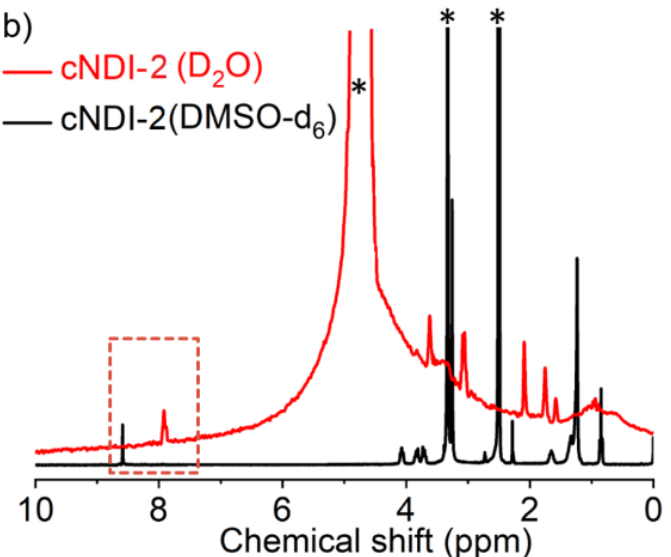

Figure S6. Solvent dependent ${ }^{1} \mathrm{H}$ NMR spectra of (a) cNDI-1 and (b) cNDI-2 ( $c=5.0 \mathrm{mM}$; asterisk indicates solvent peaks).

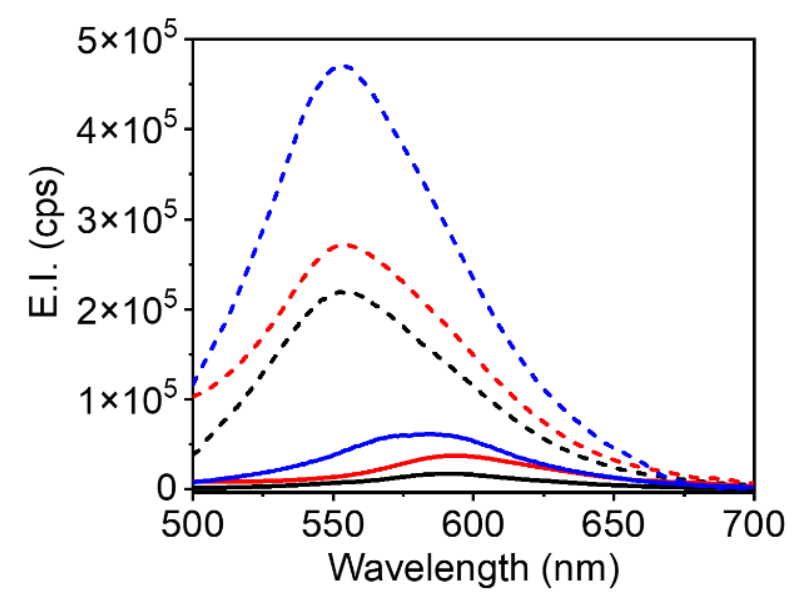

Figure S7. Solvent dependent fluorescence spectra of cNDI-1 (black), cNDI-2 (red) and cNDI -3 (blue) in THF (dashed line) and water (solid line). $c=0.1 \mathrm{mM}, l=1.0 \mathrm{~cm}, \lambda_{\mathrm{ex}}=480 \mathrm{~nm}$. 

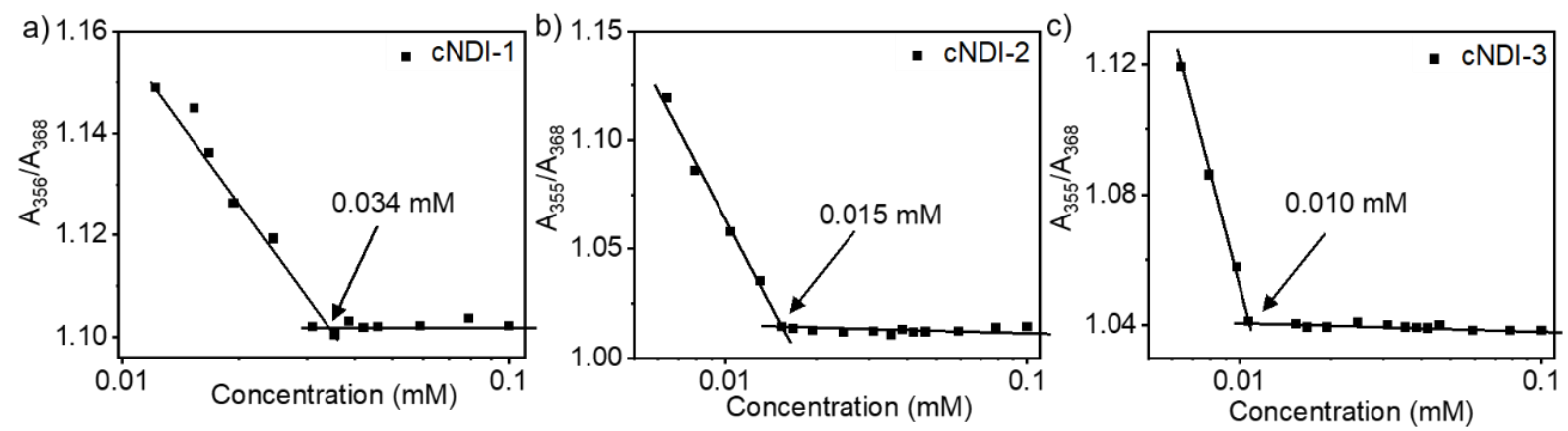

Figure S8. CAC measurements of (a) cNDI-1, (b) cNDI-2 and (d) cNDI-3 in aqueous medium

(2.0 eqv. $\mathrm{HCl}$ solution, $l=1.0 \mathrm{~cm}$ ) obtained from concentration dependent $\mathrm{UV}-\mathrm{V}$ is spectra (Ratio of absorption intensity of the two bands (356 and $368 \mathrm{~nm}$ ) has been plotted against the sample concentrations).
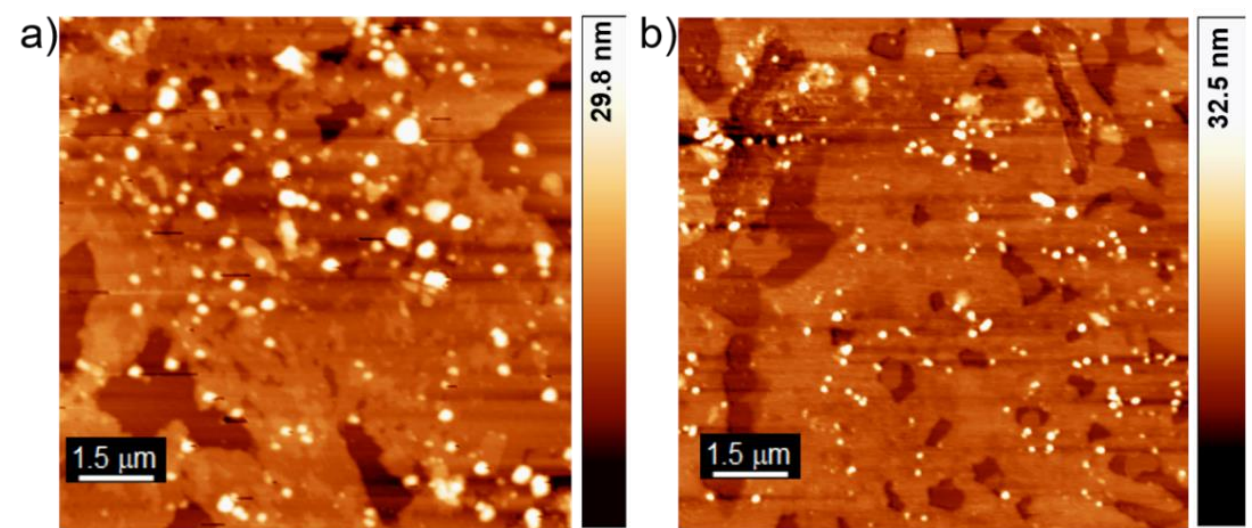

Figure S9. AFM image of the 2D-assembly of cNDI-2 after $6 \mathrm{~h}$ incubation with (a) S. aureus and (b) E. coli showing residues of killed planktonic bacteria over intact 2D-sheets (cNDI-2 sample concentration $=2 \times \mathrm{MIC}$, bacteria concentration $=5 \times 10^{5} \mathrm{CFU} / \mathrm{mL}$ ). 

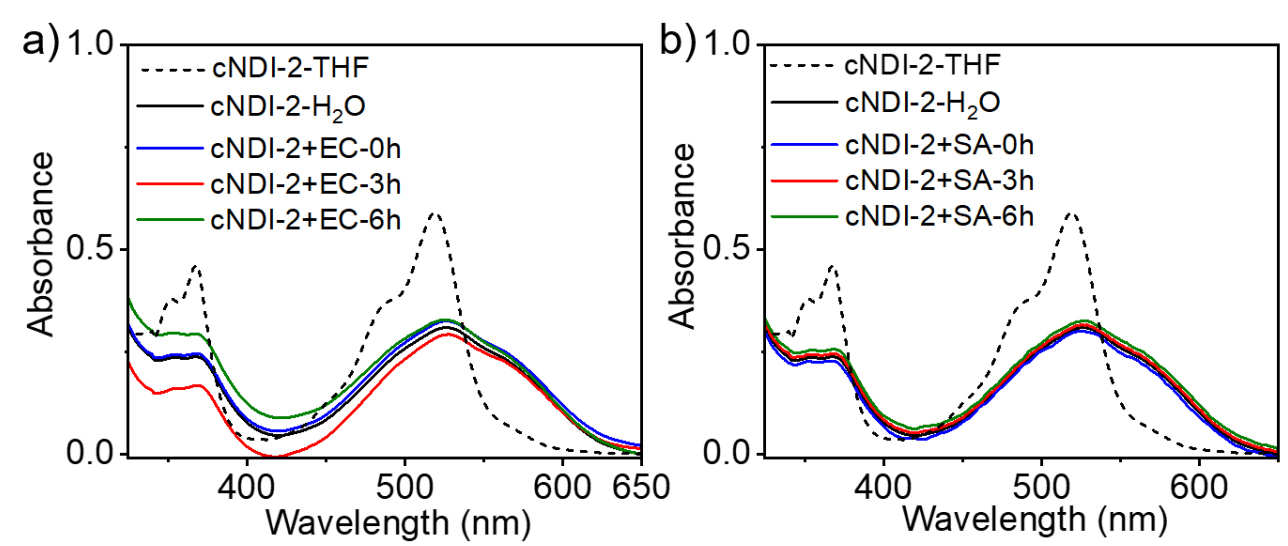

Figure S10. UV-Vis spectra of cNDI-2 solution before (indicated as $0 \mathrm{~h}$ ) and after the treatment with (a) S. aureus and (b) E. coli at $3 \mathrm{~h}$ and $6 \mathrm{~h}$ showing unaltered spectral signature (sample concentration $=2 \times \mathrm{MIC}$, bacteria concentration $=5 \times 10^{5} \mathrm{CFU} / \mathrm{mL}$ ) indicating lack of any disassembly. Dotted line shows monomeric spectrum in THF.
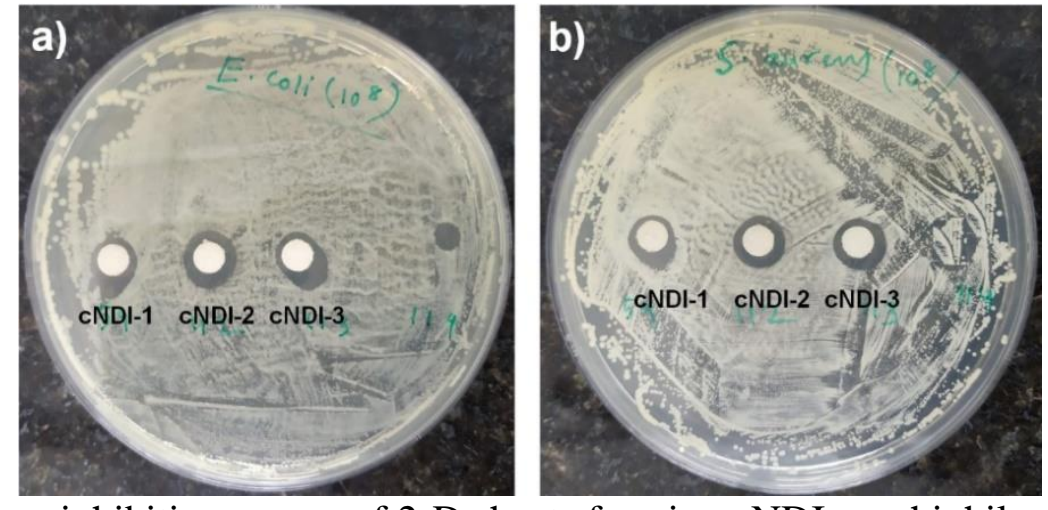

Figure S11. Zone inhibition assays of 2-D sheets forming cNDI-amphiphiles ( $c=1 \mathrm{mg} / \mathrm{mL})$ for a) E. coli b) S. aureus.

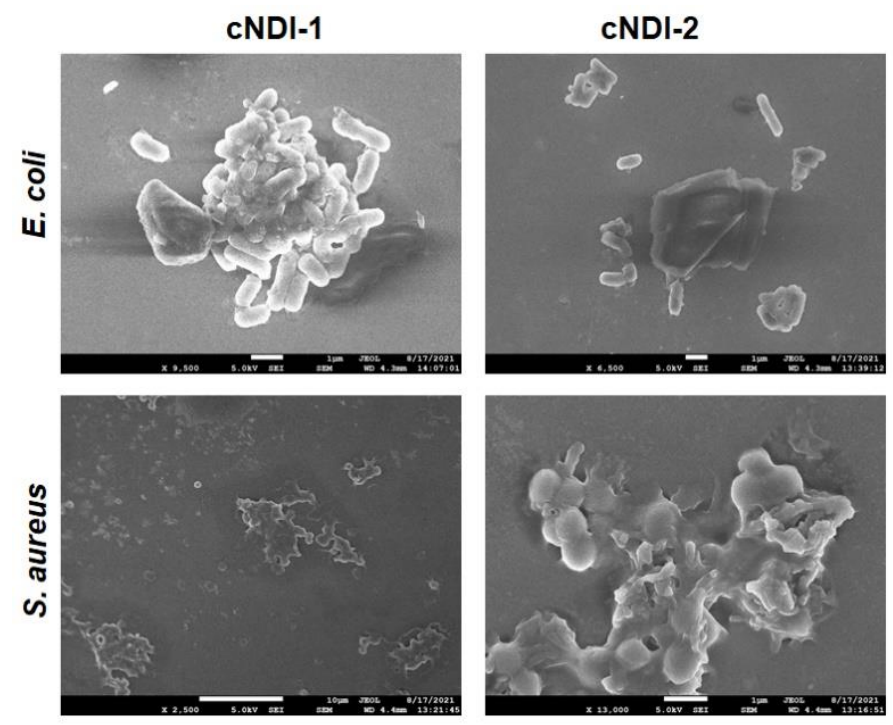

Figure S12: FESEM images of $E$. coli and $S$. aureus after the treatment with cNDI-1 and cNDI$2(c=200 \mu \mathrm{g} / \mathrm{mL})$. 

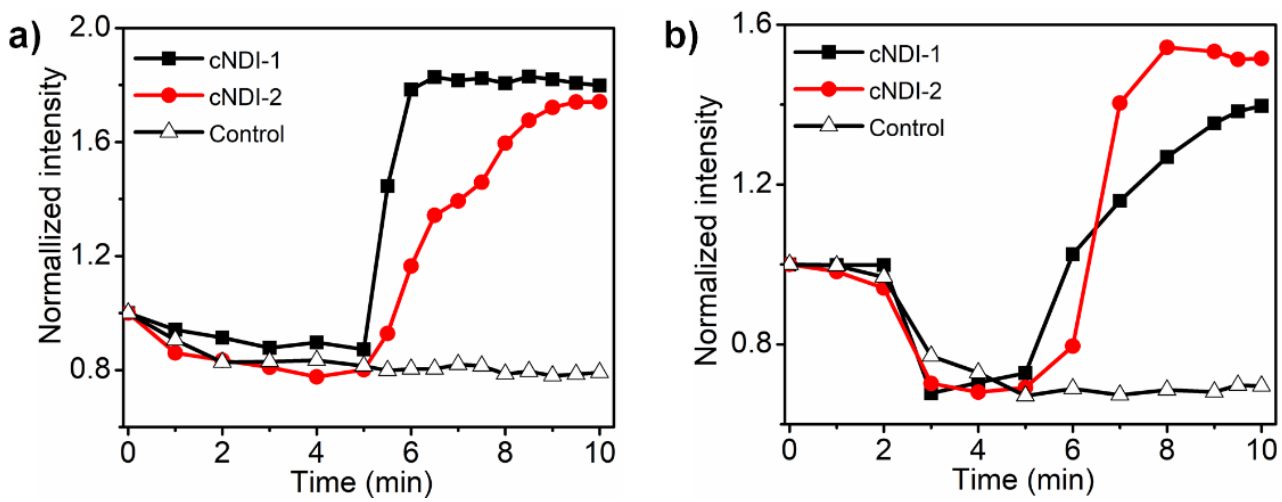

Figure S13. Cytoplasmic membrane depolarization of a) E. coli and b) S. aureus (cell concentration $\left.=2 \times 10^{7} \mathrm{CFU} / \mathrm{mL}\right)$ by $\mathrm{cNDI}-1$ and $\mathrm{cNDI}-2(c=100 \mu \mathrm{g} / \mathrm{mL})$ measuring the fluorescence intensity of potential-sensitive dye, 3,3'-dipropylthiacarbocyanine $\left(\mathrm{DiSc}_{3}-5\right)(c=$ $50 \mathrm{~nm})$.

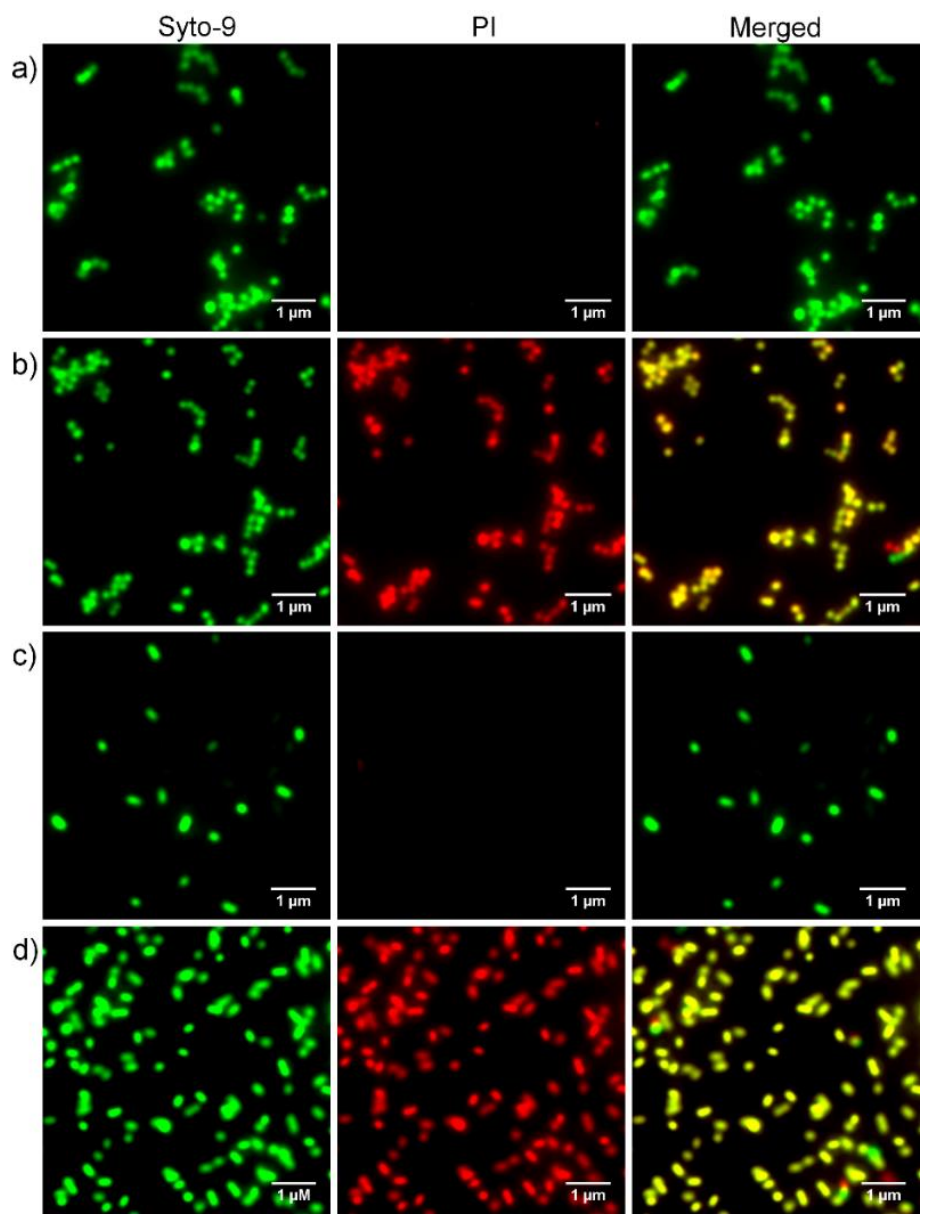

Figure S14. Fluorescence images of live (green) and dead (red) bacteria using live-dead kit (Syto-9 and propidium iodide) of S. aureus (a) before and b) after treatment with cNDIcompounds) and similarly for E. coli (c) before and (d) after treatment with cNDI-2 (c = 300 $\mu \mathrm{g} / \mathrm{mL})$. 


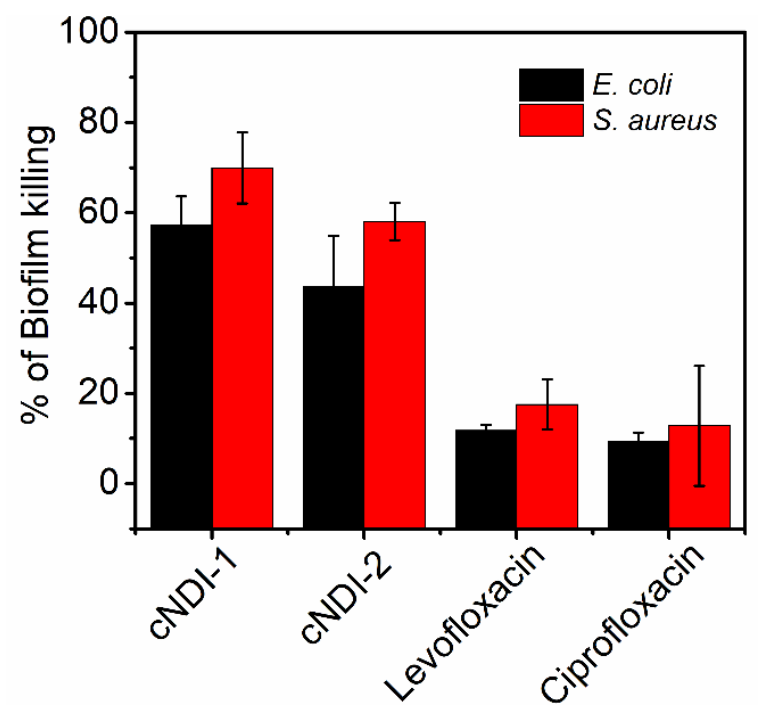

Figure S15: Killing (\%) of biofilms after treatment with cNDI-1, cNDI-2, Levofloxacin and Ciprofloxacin at $2 \times$ MIC concentrations in each case. Mean values \pm SD for three replicates is presented.

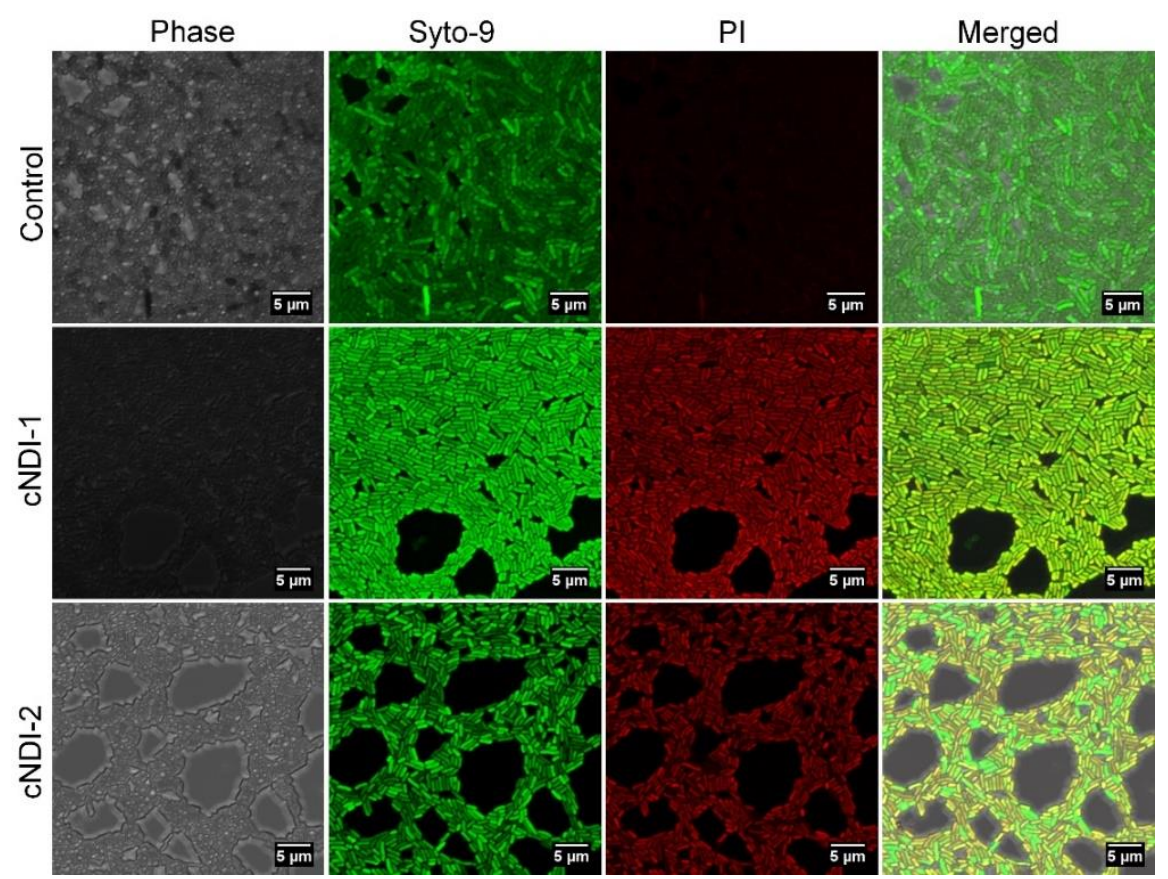

Figure S16. CLSM images of biofilm of E. coli (biofilms were grown for $24 \mathrm{~h}$ on confocal disc) before and after treatment with cNDI-1 and cNDI-2 $(c=125 \mu \mathrm{g} / \mathrm{mL})$. Biofilms were strained by live dead kit Syto-9 and propidium iodide (green: live/ viable; red: dead). 


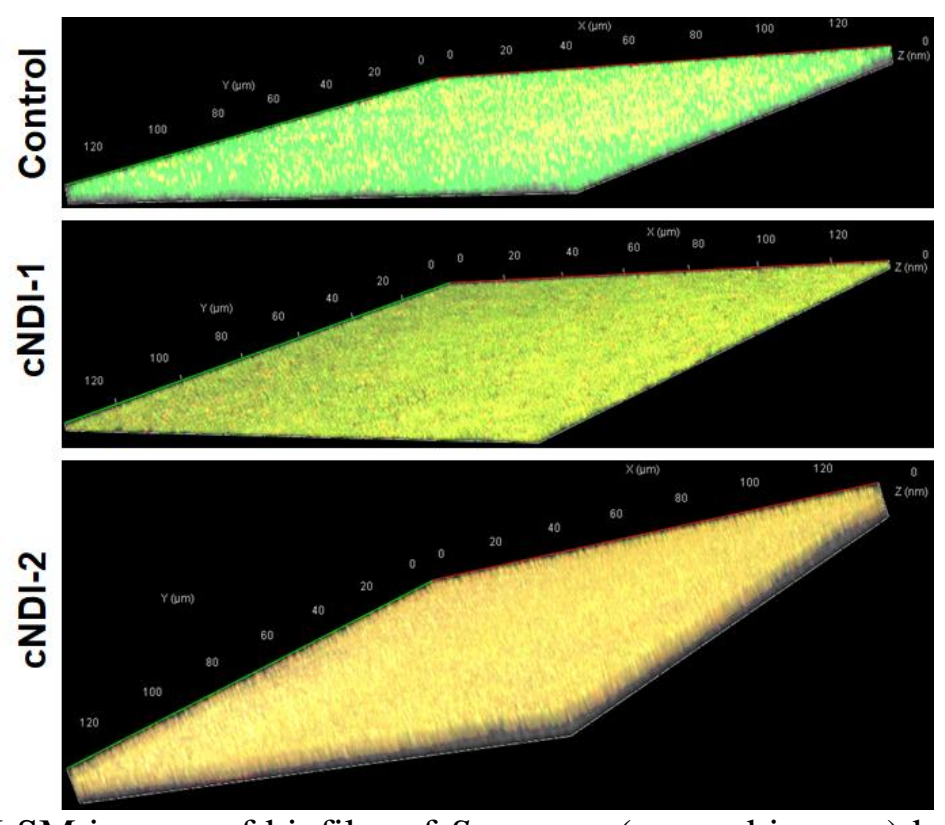

Figure S17. 3D CLSM images of biofilm of S. aureus (merged images) before (control) and after treatment with cNDI-1 and cNDI-2.
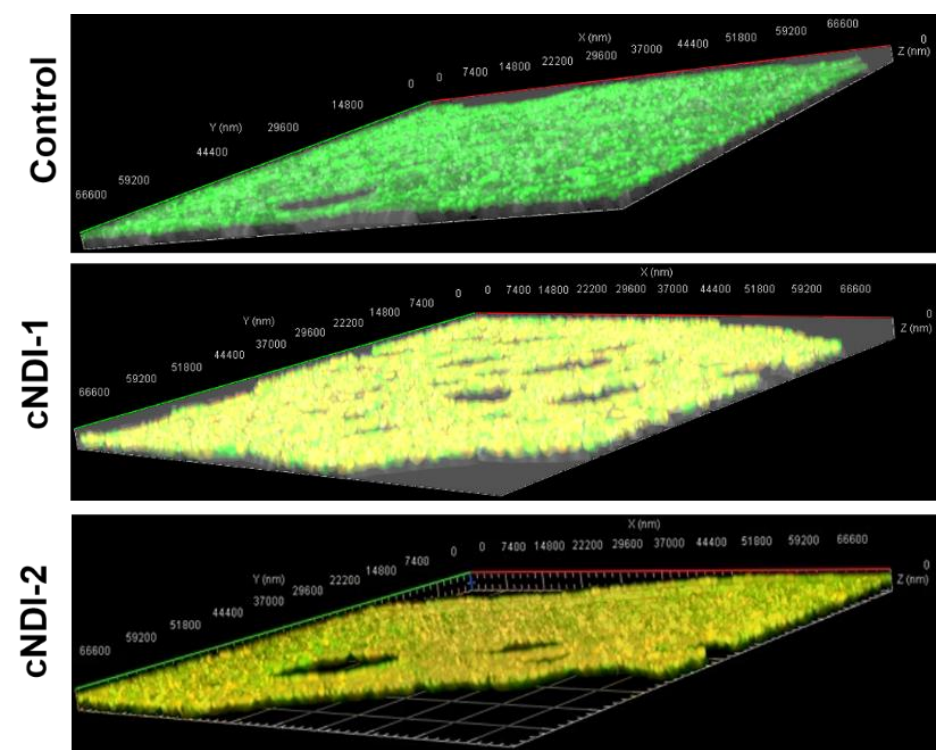

Figure S18. 3D CLSM images of biofilm of E. coli (merged images) before (control) and after treatment with cNDI-1 and cNDI-2.

\section{Theoretical Methods}

In the present study we have used Density Functional Theory (DFT) as implemented in G09 software $^{3}$ to theoretically model the molecules cNDI-1, cNDI-2 and cNDI-3. We have used the B3LYP functional ${ }^{4-6}$ and $6-31 \mathrm{G}^{* *}$ basis-set for the present study which is widely used by chemists and is known to be suitable for organic and inorganic molecules ${ }^{7}$ All stable structures 
obtained were confirmed to be minima in the potential energy surface, after calculation of vibrational frequencies, which were all positive.

\section{References}

(1) Perrin, D. D. and Armarego, W. L. F. Purification of laboratory chemicals. 3rd ed. Oxford; New York: Pergamon Press, 1988.

(2) Sasikumar, M.; Suseela, Y. V; Govindaraju, T. Dibromohydantoin: A Convenient Brominating Reagent for 1,4,5,8-Naphthalenetetracarboxylic Dianhydride. Asian J. Org. Chem. 2013, 2, 779-785.

(3) Frisch, M. J.; Trucks, G. W.; Schlegel, H. B.; Scuseria, G. E.; Robb, M. A.; Cheeseman, J. R.; Scalmani, G.; Barone, V.; Mennucci, B.; Petersson, G. A.; Nakatsuji, H.; Caricato, M.; Li, X.; Hratchian, H. P.; Izmaylov, A. F.; Bloino, J.; Zheng, G.; Sonnenberg, J. L.; Hada, M.; Ehara, M.; Toyota, K.; Fukuda, R.; Hasegawa, J.; Ishida, M.; Nakajima, T.; Honda, Y.; Kitao, O.; Nakai, H.; Vreven, T.; Montgomery, J. A.; Peralta, Jr. J. E.; Ogliaro, F.; Bearpark, M.; Heyd, J. J.; Brothers, E.; Kudin, K. N.; Staroverov, V. N.; Keith, T.; Kobayashi, R.; Normand, J.; Raghavachari, K.; Rendell, A.; Burant, J. C.; Iyengar, S. S.; Tomasi, J.; Cossi, M.; Rega, N.; Millam, J. M.; Klene, M.; Knox, J. E.; Cross, J. B.; Bakken, V.; Adamo, C.; Jaramillo, J.; Gomperts, R.; Stratmann, R. E.; Yazyev, O.; Austin, A. J. ; Cammi, R.; Pomelli, C.;Ochterski, J. W.; Martin, R. L.; Morokuma, K.; Zakrzewski, V. G.; Voth, G. A.; Salvador, P.; Dannenberg, J. J.; Dapprich, S.; Daniels, A. D.; Farkas, O.; Foresman, J. B.; Ortiz, J. V.; Cioslowski, J.; Fox, D. J.; Gaussian, Inc., Wallingford CT, 2009.

(4) Becke, A. D. Density-functional thermochemistry. III. The Role of Exact Exchange. J. Chem. Phys. 1993, 98, 5648-5652. 
(5) Becke, A. D. Density-Functional Exchange-Energy Approximation with Correct Asymptotic Behaviour. Phys. Rev. A 1988, 38, 3098-3100.

(6) Stephens, P. J.; Devlin, F. J.; Chabalowski, C. F.; Frisch, M. J. Ab Initio Calculation of Vibrational Absorption and Circular Dichroism Spectra Using Density Functional Force Fields. J. Phys. Chem. 1994, 98, 11623-11627.

(7) Liu, Y.; Liu, Y.; Gallo, A. A.; Knierim, K. D.; Taylor, E. R.; Tzeng, N. Performances of DFT Methods Implemented in G09 for Simulations of the Dispersion-Dominated $\mathrm{CH}-\pi$ in Ligand-Protein Complex: A Case Study with Glycerol-GDH. J. Mol. Struct. 2015, 1084, 223-228. 